\title{
Mathematics in poetry
}

\section{Stephen Ornes}

Science Writer

The universe is a grand book, Galileo noted in 1623 , written in the language of mathematics (1). Those poor souls who don't understand that language, he cautioned, wander about in a "dark labyrinth."

As languages go, mathematics can be intimidating. Plenty of people linger in the shade of Galileo's labyrinth. To the uninitiated, equations, theorems, and proofs-to say nothing of their constituent postulates, lemmata, and corollaries-can read like dispatches from an aloof and unsociable otherworld.

To others, mathematics can be poetry. A small but robust genre- all it math-fueled poetry-attracts mathematicians and poets alike who find creative inspiration at the intersection.

Sarah Glaz at the University of Connecticut, Storrs, declares herself first and foremost a mathematician, but admits her research in abstract algebra seeps into her poems. In "Calculus," Glaz invokes not only the machinery of derivatives and integrals, but also teaching experiences and the contentious history of the field's origins. "I tell my students the story of Newton versus Leibniz," the poem begins, "the war of symbols, lasting five generations..."

In 2008, she and fellow mathematicianpoet JoAnne Growney edited Strange Attractors: Poems of Love and Mathematics, a collection of 150 math-related poems. Growney, an algebraist who retired in 1997 from Bloomsburg University in Pennsylvania, also blogs about the intersection of math and poetry, with an emphasis on women in mathematics. She also helped organized a poetry reading at the upcoming Joint Mathematics Meeting in January 2014 in Baltimore.

The intersection of math and poetry is well trodden: Writing in the Journal of

Because I Longed by Elizabeth Bartlett

Because I longed

To comprehend the infinite

I drew a line

Between the known and unknown

Excerpt from: Treatise on Infinite Series by Jacob Bernoulli

Even as the finite encloses an infinite series

And in the unlimited limits appear,

So the soul of immensity dwells in minutia

And in narrowest limits no limits inhere.

What joy to discern the minute in infinity!

The vast to perceive in the small, what divinity!

Mathematics and the Arts in 2011, Glaz posits that math and poetry have been "intertwined" for almost as long as people have been writing (2). Ancient Sumerians wove mathematical ideas into their hymns; the ancient Greek philosopher Archimedes originated the "cattle problem" through verse. (The poem asked how many cattle belonged to the sun god, according to given mathematical limitations. The answer, calculated in 1880 , turned out to be $7.76 \times 10^{206,544}$ cattle.)

Jacob Bernoulli, a pioneer in probability and discoverer of e, celebrated mathematical limits with poetry; Pablo Neruda, John Updike, Elizabeth Bartlett, and dozens of others have similarly been inspired. The Polish poet Wislawa Szymborska, winner of the 1996 Nobel Prize in Literature, frequently invoked mathematical ideas in her work.

Glaz says friendly controversy divides the genre. "People try to define what mathematical poetry is, but everyone has a different view," she says. There are two types, she says: poems with words and visual poems that use mathematical symbols in specific way, often eschewing the use of words altogether. So can an equation be a poem? "This is a sensitive subject," she says.

Glaz thinks similar creative processes drive the acts of doing mathematics and writing poetry: "It's the combination of something that arouses curiosity and inspiration, and then there's some perspiration. And some frustration," she says. "Sometimes it doesn't work, and sometimes, happily, it works, in spite of you."

1 Drake S, trans. (1957) Discoveries and Opinions of Galileo (Doubleday \& Co, New York).

2 Glaz S (2011) Poetry inspired by mathematics: A brief journey through history. J Mathematics Arts 5(4):171-183. 